\title{
Cloning of the $N$-acylamino acid racemase gene from Amycolatopsis azurea and biochemical characterization of the gene product
}

\author{
Shiun-Cheng Su, Chia-Yin Lee* \\ Graduate Institute of Agricultural Chemistry, National Taiwan University, Taipei 106, Taiwan
}

Received 6 August 2001; received in revised form 11 December 2001; accepted 20 December 2001

\begin{abstract}
A gene encoding $N$-acylamino acid racemase (NAAAR) from Amycolatopsis azurea CCRC13413 was cloned. An analysis of its sequence revealed an open reading frame encoding 368 amino acid residues. The deduced amino acid sequence of NAAAR showed an $89 \%$ identity with that of Amycolatopsis sp. TS-1-60. The $N$-acylamino acid racemase gene (aaar) was subcloned into expression vector pET-17b, and was transformed into E. coli BL21 (DE3). A 41-kDa protein band was present on the SDS-PAGE gel from the intracellular soluble part of E. coli. The recombinant NAAAR produced in E. coli was purified by Toyopearl DEAE-650M and Sephacryl S-200 h chromatography. The molecular weight of NAAAR, determined by gel-filtration chromatography, was 320 kDa, indicating that NAAAR was composed of eight identical subunits. NAAAR had maximal activity at $40^{\circ} \mathrm{C}$ and $\mathrm{pH} 7.4$. The enzyme activity was enhanced notably by $\mathrm{Co}^{2+}$ and $\mathrm{Mn}^{2+}$. Substrate specificity revealed that $N$-acetyl-D-methionine, $N$-acetyl- L-methionine, $N$-acetyl-D-tyrosine, $N$-acetyl-Lvaline, and $N$-chloroacetyl -D-phenylalanine were the effective substrates. For the substrate $N$ - acetyl-D-methionine, $K_{\mathrm{m}}$ was $27.8 \mathrm{mM}$ with a $V_{\max }$ of $0.07 \mu \mathrm{mol}^{-1} \mathrm{~min}^{-1}$ and a $k_{\mathrm{cat}} / K_{\mathrm{m}}$ of $311.4 \mathrm{M}^{-1} \mathrm{~s}^{-1}$. Our data revealed that this $N$-acylamino acid racemase has a broad substrate range. In addition, we procured the distribution of sequence-conserved regions from known NAAARs and putative NAAARs in this study. (C) 2002 Elsevier Science Inc. All rights reserved.
\end{abstract}

Keywords: $N$-acylamino acid racemase; Optically active amino acid; $o$-succinylbenzoate synthase; Enolase superfamily

\section{Introduction}

Optically active D-amino acids are widely used as intermediates in the synthesis of semisynthetic antibiotics, peptide hormones, and pesticides, and they are important chiral building blocks for a number of fine chemicals such as pharmaceuticals, agrochemicals, and food additives [1,2]. Several attempts have been made to synthesize D-amino acids enzymatically [3-5], including the process of coupling $\mathrm{N}$-acylamino acid racemase and D-aminoacylase, using $N$ acetyl-D, L-amino acid as substrates [6-9]. The final yield of D-amino acids can approach more than $99 \%$, which is higher than the $50 \%$ yield from the enzymatic resolution of racemic $N$-acetyl amino acids by $\mathrm{D}$-aminoacylase alone. $N$-acylamino acid racemase (NAAAR) is a specific enzyme that catalyzes the racemization of optical $N$-acylamino acids but not of optical amino acids. According to the report [6],

\footnotetext{
* Corresponding author. Tel.: +886-2-23630231 ext 2816; fax: +886-2 23660581.

E-mail address: M477@ccms.ntu.edu.tw (C.-Y. Lee).
}

NAAAR is widely distributed among actinomycetes, including the genera Streptomyces, Actinomadura, Actinomyces, Jensenia, Amycolatopsis, and Sebekia. NAAAR is a unique racemase that requires divalent metal ions for enzyme activity but not pyridoxal 5'-phosphate. Having been placed into the enolase superfamily, $N$-acylamino acid racemase retains the ability to catalyze the thermodynamically difficult step of proton abstraction [10]. The enzymes of the enolase superfamily are related by their ability to catalyze the abstraction of the $\alpha$-proton of a carboxylic acid to form an enolic intermediate.

$\mathrm{N}$-acetyl-D, L-amino acids have already been used as substrates in producing L-amino acids by using immobilized L-aminoacylases in an industrial processes [11]. Now, it is discovered that NAAAR has been found could catalyze the racemization of $N$-acyl-D- or L-amino acids. When coupled with suitable aminioacylase, this process for produce optically active amino acids prevents additional separation procedure. Therefore, the NAAAR enzyme is considered to be very important for industrial applications. In this paper, we tried screening several actinomycetes strains 
Table 1

Strains and plasmids used in this study

\begin{tabular}{|c|c|c|}
\hline Strain or plasmid & Relevant characteristic & Source or reference \\
\hline \multicolumn{3}{|l|}{ Strains } \\
\hline $\begin{array}{l}\text { Amycolatopsis azurea } \\
\qquad(\text { CCRC13413, IFO14573) }\end{array}$ & $N$-acylamino acid racemase producer & This study \\
\hline E. coli XL1-Blue & $\begin{array}{l}\text { Gene cloning host; rec } \mathrm{A} 1 \text { end } \mathrm{A} 1 \text { gyr } \mathrm{A} 46 \text { thi hsd } \mathrm{R} 17 \text { supE44 relAl lac } \mathrm{F} \text { '[pro } \mathrm{AB} \\
\quad \text { lacl }^{\mathrm{q}} \text { lacZ } \Delta \mathrm{M} 15 \mathrm{Tn} 10\left(\text { tet }^{\mathrm{r}}\right)\end{array}$ & Bullock et al. [27] \\
\hline E. coli BL21 (DE3) & $\begin{array}{l}\text { Gene expression host; DE3 lysogen of BL21 encoding lacl, the lacUV5 promoter and the } \\
\text { gene for T7 RNA polymerase for T7 RNA polymerase }\end{array}$ & Novagen \\
\hline \multicolumn{3}{|l|}{ Plasmids } \\
\hline pGEM-T easy & Gene cloning vector; $\mathrm{Ap}^{\mathrm{r}}$ lac $Z$ & Promega \\
\hline pAr1 & $\mathrm{Ap}^{\mathrm{r}}$, aaar $^{+}, 1140 \mathrm{bp}$ fragment carrying aaar & This study \\
\hline pET17b & Gene expression vector, $\mathrm{Ap}^{\mathrm{r}}$ & Novagen \\
\hline pAr3 & $\begin{array}{l}\mathrm{Ap}^{\mathrm{r}}, \text { aaar }^{+}, 1127 \mathrm{bp} \text { fragment modified form pAr1, digested by SacI and XhoI then cloned } \\
\text { into pET17b/SacI; the T7tag on the vector had been delete by NdeI and HindIII }\end{array}$ & This study \\
\hline
\end{tabular}

for the production of the $N$-acylamino acid racemase. We cloned a aaar gene from Amycolatopsis azurea CCRC13413 by polymerase chain reaction (PCR), overexpressed it in E. coli cells, and purified it, as well as biochemically characterizing the gene product. Although the $N$-acylamino acid racemase has been discovered from Amycolatopsis sp. TS-1-60 [7-9] and Amycolatopsis orientalis subsp. lurida [12], there are some kinetic problems restricting its application in commercial processes. In this study, we procured the distributions of sequence-conserved regions from the known NAAARs and putative NAAARs. In order to overcome the problems associated with using this enzyme, protein engineering could be used. Before we obtaining NAAAR's crystal structure, the information from enzyme characterization and sequences alignment would be valuable for further study.

\section{Materials and Methods}

\subsection{Materials}

$N$-acyl-D- or L-amino acids, and D- or L-amino acids were purchased from Sigma Chemical (St Louis, MO, USA) and BACHEM (Bubendorf, Switzerland). L-aminoacylase, horse radish peroxidase, and 4-aminoantipyrine were purchased from Sigma. Meat extract, peptone, and trypticase soy broth were obtained from Difco Lab. (Detroit, MI, USA). ChiroBiotic T $(0.46 \times 25 \mathrm{~cm})$ was purchased from Astec (Whippany, NJ, USA). Other chemical reagents were obtained from Riedel-deHaën ( $\mathrm{RdH}$ Laborchemikalien $\mathrm{GmbH}$ ).

\subsection{Bacterial strains, plasmids, and culture conditions}

Six actinomyces were collected from the Culture Collection and Research Center of Taiwan's Food Industry Research and Development Institute. They were grown at $28^{\circ} \mathrm{C}$ in Trypticase soy broth, and their capability for producing NAAAR was evaluated by chiral-HPLC assay. $E$. coli XL1-Blue and E. coli BL21(DE3) were grown at $37^{\circ} \mathrm{C}$ in Luria-Bertani broth; these were used as a transformation host and an expression host, respectively. Strains and plasmids used in this study are listed in Table 1.

\subsection{Cloning of the aaar gene and recombinant DNA techniques}

The presence of the aaar gene in our collected strains was screened by PCR amplification using two primers: 5' -TGCGGATCAAGCTTAAGATCG-3' (designated F2) and 5'-TTTGATGTTCACGATTTGGACCGCGC -3' (designated 10I). The genomic DNA of the collected strains was prepared according to "current protocols in molecular biology" [13], and this was used as templates for PCR. The PCR primers were designed based on the aaar gene sequence of Amycolatopsis sp. TS-1-60 (accession number D30738). According with results from the PCR reaction, Amycolatopsis azurea CCRC13413 was selected, and the aaar gene was cloned as follows. We used $p f u$ DNA polymerase (Promega) and primers $5^{\prime}$-GTGAAACTCAGCGGTGT-3' (designated aaarPF1) and 5'-CCGACCAAATCTACCTCC-3' (designated aaarR1), to amplify the aaar gene by the PCR method. The PCR primer pair, aaarPF1 and aaarR1, were designed from $5^{\prime}$ and $3^{\prime}$ ends of the aaar gene sequence of Amycolatopsis sp. TS-1-60, respectively. Amplified aaar DNA fragments were purified with a QIAquick Gel-extraction kit (Qiagen). The generation of T-A overhangs for the DNA fragment, described as "current protocols in molecular biology," these were then ligated with pGEM-T easy vector (Promega) to obtain the recombinant plasmid, pAr1.

\subsection{DNA sequence determination and analysis}

The nucleotide sequence of aaar gene in pAr1 was determined by the dideoxynucleotide chain-termination method [14] with an ABI PRISM BigDye Terminator Cycle Sequencing Ready Reaction Kit and an ABI PRISM 377-96 DNA sequencer (Perkin-Elmer, Applied Biosystems, Faster 
city, CA, USA). The nucleotide sequence data reported in this paper will appear in the DDBJ/EMBL/GenBank nucleotide sequence database with accession number AF335269. The amino acid sequence was compared by PSI-BLAST [15], and the multiple sequence alignment was achieved by Clustal W, [16].

\subsection{Enzyme purification}

E. coli BL21(DE3) harboring pAr3 (Table 1) was subcultured at $37^{\circ} \mathrm{C}$ for 10 -h in a test tube containing $3 \mathrm{ml}$ Luria-Bertani medium, supplemented with $100 \mu \mathrm{g}$ ampicillin $\mathrm{ml}^{-1}$. The subculture was then inoculated into 500-ml flasks, each containing $100 \mathrm{ml}$ Luria-Bertani medium, supplemented with $100 \mu \mathrm{g}$ ampicillin $\mathrm{ml}^{-1}$ ampicillin. After a 4-h incubation at $37^{\circ} \mathrm{C}$ on a rotary shaker at $150 \mathrm{rpm}$, isopropylthio- $\beta$-D-galactoside (at a final concentration of $0.1 \mathrm{mM}$ ) was added to the culture broth, and incubation was continued for another $24 \mathrm{~h}$ at $28^{\circ} \mathrm{C}$ with reciprocal shaking. All purification procedures were performed at a temperature lower than $5^{\circ} \mathrm{C}$, unless otherwise noted. The buffer used throughout this study was Tris/ $\mathrm{HCl}(\mathrm{pH} 7.5,50 \mathrm{mM})$. Then cells were harvested by centrifugation at $8,000 \mathrm{~g}$ for $10 \mathrm{~min}$ at $4^{\circ} \mathrm{C}$ and washed with buffer. The $0.6-\mathrm{L}$ culture was suspended in $30 \mathrm{ml}$ of buffer and was disrupted by sonication for $7 \mathrm{~min} 30 \mathrm{~s}$ (Sonicator, Ultrasonic processor XL, Heat Systems), followed by centrifugation at $12,000 \mathrm{~g}$ for $30 \mathrm{~min}$ at $4^{\circ} \mathrm{C}$. The supernatant solution was loaded onto a DEAE Toyopearl 650M (Tosoh Tokyo, Japan) column $(1.6 \times 12 \mathrm{~cm})$ pre-equilibrated with buffer, and the adsorbed protein was eluted with a linear gradient of $0 \sim 0.5 \mathrm{M}$

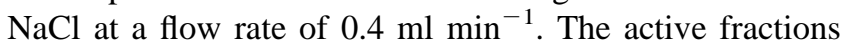
were combined, concentrated by centriprep YM-10 (Amicon), and then applied to a Sephacryl S-200 h column, equilibrated with $50 \mathrm{mM}$ buffer containing $150 \mathrm{mM} \mathrm{NaCl}$. The column was eluted at $0.2 \mathrm{ml} \mathrm{min}{ }^{-1}$, and the active fractions were collected and assayed.

\subsection{Enzyme assay}

$\mathrm{N}$-acylamino acid racemase activity was assayed as follows. The reaction mixture $(0.5 \mathrm{ml})$ contained Tris $/ \mathrm{HCl}$ buffer (25 $\mu \mathrm{mol}, \mathrm{pH}$ 7.5), $N$-acetyl-D-methionine (12.5 $\mu \mathrm{mol}), \mathrm{Co}^{2+}(1 \mu \mathrm{mol})$, and an appropriate amount of the enzyme. After the addition of enzymes, the mixture was incubated at $30^{\circ} \mathrm{C}$ for $30 \mathrm{~min}$, and the reaction was discontinued by heating at $95^{\circ} \mathrm{C}$ for $5 \mathrm{~min}$. Optical resolution and simultaneous measurement of $N$-acyl-D-methionine, $N$-acyl-L-methonine, D-methionine, and L-methionine from the enzyme reaction mixture were conducted using a ChiroBiotic T column $(0.46 \times 25 \mathrm{~cm})$ (Astec). The flow rate was $0.5 \mathrm{ml} \mathrm{min}{ }^{-1}$ using $0.1 \%$ triethyl acetic acetate (TEAA, $\mathrm{pH} 4.0), \mathrm{dH}_{2} \mathrm{O}$, and methanol $(5: 15: 80, \mathrm{v} / \mathrm{v})$ as a solvent, under monitorization at $210 \mathrm{~nm}$ [17].

NAAAR activity was also measured spectrophotometrically at $520 \mathrm{~nm}$ by coupling the oxidation of L-amino acids with L-amino acid oxidase. The reaction mixture was prepared as described previously, and then $5 \mathrm{U}$ of L-aminoacylase was added, and the mixture was incubated for another $30 \mathrm{~min}$ at $30^{\circ} \mathrm{C}$. The assay mixture was comprised of $0.07 \mathrm{U}$ L-amino acid oxidase, $7.5 \mu \mathrm{mol}$ Tris/ $\mathrm{HCl}(\mathrm{pH} 7.5)$, $10 \mu \mathrm{l}$ of test sample, and $20 \mu \mathrm{l}$ of detection reagent (containing $500 \mathrm{U}$ horse radish peroxidase, $10 \mathrm{mg} 4$-aminoantipyrine, $0.2 \mathrm{ml}$ phenol, and $50 \mathrm{mM}$ potassium phosphate, $\mathrm{pH} 7.2$, in a final volume of $5 \mathrm{ml}$ ). The reaction mixture was incubated for $10 \mathrm{~min}$ at room temperature, and the absorbance at $520 \mathrm{~nm}$ was compared with a calibration curve obtained using L-methionine. One unit of enzyme activity was defined as the amount of enzyme catalyzing the forma-
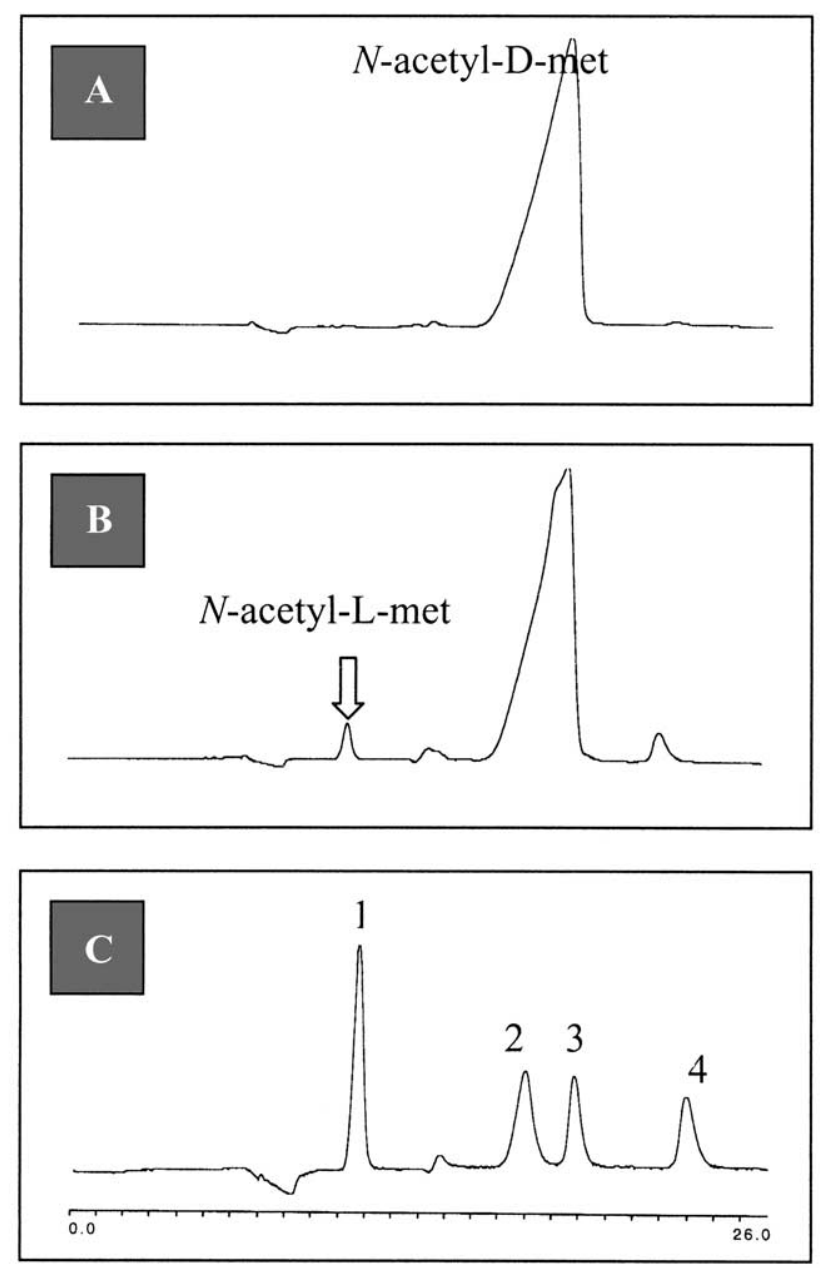

Fig. 1. Activity assay of the $N$-acylamino acid racemase by chiral-HPLC. Amycolatopsis azurea CCRC13413 was the source of the gene of $\mathrm{N}$ acylamino acid racemase, as assayed by the chiral-HPLC method. Threeday cultures were collected, lysed, and then the supernatant was used as the crude enzyme to detect the enzyme reaction. Enzyme reaction was performed under standard conditions, except with a reaction time of 20-h. The chiral-HPLC assay method is described in "Materials and methods." (A) Reaction containing the reaction substrate $(25 \mathrm{mM} \mathrm{N}$-acetyl-D-methionine); (B) Reaction containing the crude enzyme and substrate. An arrow indicates the product, $N$-acetyl-L-methionine; (C) Standards $(0.5 \mathrm{mM})$ of $N$-acetyl-L-methionine, 1 ; $N$-acetyl-D-methionine, 2; L-methionine, 3 ; and D-methionine, 4. 
Table 2

Pairwise sequence identities of relating the putative $N$-acylamino acid racemase

\begin{tabular}{|c|c|c|c|c|c|c|c|c|}
\hline & $\begin{array}{l}\text { Amycolatopsis } \\
\text { azurea }\end{array}$ & $\begin{array}{l}\text { Amycolatopsis } \\
\text { orientalis } \\
\text { subsp lurid }\end{array}$ & $\begin{array}{l}\text { Amycolatopsis } \\
\text { sp. TS-1-60 }\end{array}$ & $\begin{array}{l}\text { D. radiodurans } \\
\text { (AE001826) }\end{array}$ & $\begin{array}{l}\text { D. radiodurans } \\
\text { (AE001867) }\end{array}$ & $\begin{array}{l}\text { Bacillus } \\
\text { subtilis }\end{array}$ & $\begin{array}{l}\text { Aeropyrum } \\
\text { pernix }\end{array}$ & $\begin{array}{l}\text { Thermoplasma } \\
\text { acidophilum }\end{array}$ \\
\hline $\begin{array}{l}\text { Amycolatopsis azurea } \\
\quad \text { (AAF335269) }\end{array}$ & 368 & $95 \%$ & $89 \%$ & $44 \%$ & $44 \%$ & $39 \%$ & $46 \%$ & $39 \%$ \\
\hline $\begin{array}{l}\text { Amycolatopsis orientalis subsp } \\
\text { lurid (AJ292519) }\end{array}$ & & 368 & $91 \%$ & $45 \%$ & $45 \%$ & $45 \%$ & $50 \%$ & $42 \%$ \\
\hline $\begin{array}{l}\text { Amycolatopsis sp. TS-1-60 } \\
\text { (D30738) }\end{array}$ & & & 368 & $47 \%$ & $46 \%$ & $43 \%$ & $50 \%$ & $41 \%$ \\
\hline D. radiodurans (AE001826) & & & & 395 & $65 \%$ & $42 \%$ & $48 \%$ & $39 \%$ \\
\hline D. radiodurans (AE001867) & & & & & 375 & $42 \%$ & $46 \%$ & $40 \%$ \\
\hline Bacillus subtilis (AF008220) & & & & & & 371 & $45 \%$ & $39 \%$ \\
\hline Aeropyrum pernix (AP000060) & & & & & & & 398 & $42 \%$ \\
\hline $\begin{array}{l}\text { Thermoplasma Acidophilum } \\
\text { (AL445063) }\end{array}$ & & & & & & & & 361 \\
\hline
\end{tabular}

Words in bold italics means the number of protein acid residues; the percentages means the identity of the two comparative protein sequences. For example, the $N$-acylamino acid racemase of Amycolatopsis sp. TS-1-60 had 368 residues possessing 89\% identity, compared with that of Amycolatopsis azurea.

tion of $1 \mu \mathrm{mol} \mathrm{L-methionine} \min ^{-1}$ under standard assay conditions.

Protein was determined by the Bradford method [18]. To determine the Michaelis constants, the reaction was performed by the enzyme assay method as described above, with different concentrations of $N$-acetyl-D-methionine and $\mathrm{N}$-acetyl-D-phenylalanine. The inhibition test was evaluated by using 2 to $200 \mu \mathrm{M}$ of salicylhydroxamate.

\subsection{Determination of the relative molecular mass}

The molecular mass of the native enzyme was determined by gel filtration using a TSK G-3000 SW column $\left(0.75 \times 30 \mathrm{~cm}\right.$, Tosoh), at a flow rate of $0.5 \mathrm{ml} \mathrm{min}^{-1}$, with $0.1 \mathrm{M}$ potassium phosphate, $\mathrm{pH} 7.0$, containing $0.1 \mathrm{M}$ $\mathrm{Na}_{2} \mathrm{SO}_{4}$ at room temperature. The molecular mass of the enzyme was then calculated from the relative mobility compared with those of standard proteins, thyroglobulin (670 $\mathrm{kDa})$, gamma globulin (158 kDa), ovalbumin (44 kDa), myoglobin (17 kDa), and vitamin B-12 (1.4 kDa) (Bio-Rad).

\section{Results}

\subsection{Identification and cloning of an aaar gene from Amycolatopsis azurea CCRC 13413}

According to the sequence alignment of $\beta$-barrel domain members of the enolase superfamily [10], two conserved regions could be chosen as PCR primers to detect the $\mathrm{N}$-acylamino acid racemase gene. The primers, F2 and 10I, contained the region that acts as the putative acid/base catalyst residue; sequences of both primers are listed in "Materials and Methods." Six strains of actinomyces were screened for the presence of the aaar gene, and one strain of the Amycolatopsis azurea CCRC13413 harbored a major
PCR product at the predicted size of $317 \mathrm{bp}$. This culture was grown in TSB for three days, and afterwards centrifuged, with the cells disrupted by sonication. The resulting crude extracts showed NAAAR activity, as analyzed by the chiral-HPLC method (Fig. 1).

The entire aaar gene in A. azurea CCRC13413 was then amplified by PCR with aaarPF1 and aaarR1 primers and was cloned into the pGEM-T easy vector. The recombinant plasmid pAr1 containing a 1140-bp fragment was screened. It was sequenced in both directions, and the nucleotide sequencing of this fragment revealed the presence of an open reading frame, consisting of $1104 \mathrm{bp}$ and coding for a protein of 368 amino acids, with a predicted molecular mass of 39,550 Da.

\subsection{Nucleotide sequence analysis and sequence alignment of NAAARs}

The nucleotide sequence of aaar from A. azurea CCRC 13413 revealed relatively high similarity with seven proteins in databases (Table 2). Alignment by the PSI-BLAST program presented that the deduced amino acid of NAAAR from Amycolatopsis azurea CCRC13413 of 89\% and 95\% identity, compared with that of Amycolatopsis sp. TS-1-60 [8] and Amycolatopsis orientalis subsp. lurida [12], respectively. This NAAAR protein also displayed 46\%, 39\%, $44 \%$, and $39 \%$ identity with the probable NAAAR of Aeropyrum pernix, Thermoplasma acidophilum, Deinococcus radiodurans, and ytfD of Bacillus subtilis, respectively [19-22] (Table 2). Alignment of these eight related proteins is shown in Fig. 2. The KXK functional motif (K161, K163), acid/base catalysis site (K263), and the predicted metal ion ligand residues (D179, D239, E214) were conserved in the NAAAR of Amycolatopsis azurea CCRC13413, along with other related proteins. From the sequence alignment, we found a Mandelate racemase/mu- 


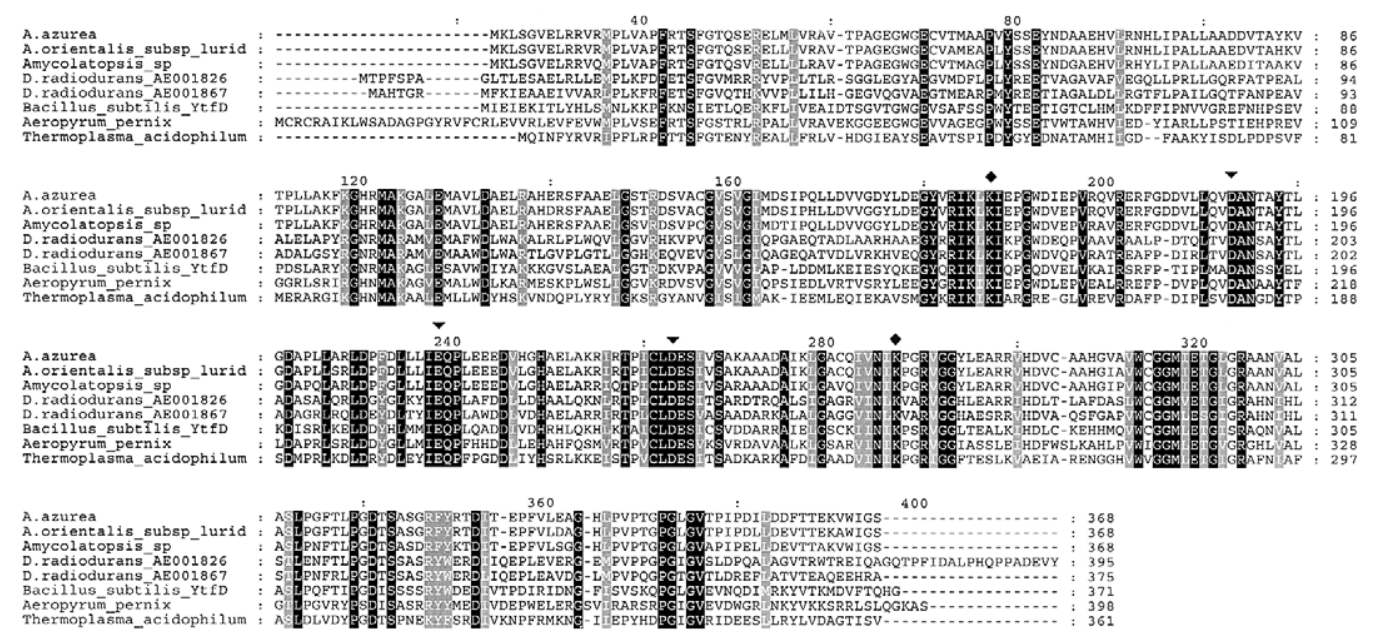

Fig. 2. Comparison of the amino acid sequences of $N$-acylamino acid racemase from Amycolatopsis azurea CCRC13413 and other homologous proteins. Amycolatopsis sp. TS-1-60, Amycolatopsis orientalis subsp. lurida, Bacillus subtilis, and other probable $N$-acylamino acid racemase from Aeropyrum pernix, Deinococcus radiodurans, Thermoplasma acidophilum. Sequence alignment by CLUSTAL W (1.81). Conserved residues are symbolized in black boxes; similarity residues are symbolized in gray boxes; acid/base catalysis sites are indicated by " $\bullet$ "; and predicted metal ion binding residues are indicated by

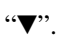

conate lactonizing enzyme $\mathrm{N}$-terminal domain between amino acid residues 1 to 124 , and a Mandelate racemase/ muconate lactonizing enzyme C-terminal domain between amino acid residues 169 to 360 .

\subsection{Expression of the aaar gene in E. coli and enzyme purification}

The aaar gene was amplified with primers Ar-Sac (5'-GCGGGAGCTCGATTATGAAACTCA-3') and ArXho3 (5'-TCTACCTCGAGAATTCGTAGTTGGCTA-3'). Primer Ar- Sac introduced a SacI site (underlined sequence), replacing the GTG start codon with ATG (bold letters) at the translation start codon; primer Ar-Xho3 introduced an XhoI site (underlined sequence) at the stop codon. Amplified DNA containing the aaar gene was cloned into the protein fusion vector, pET17b, as a $S a c I-X h o I$ fragment. This plasmid was designated pAr2. Finally, we deleted the T7 tag site on pAr2 by digestion with NdeI and HindIII, which yielded plasmid pAr3. Expression of $E$. coli BL21(DE3) was performed as recommended by the supplier (Novagen). The specific activity of $N$-acylamino acid racemase in the supernatant of sonicated cell-free extracts of transformants was $30 \mathrm{mU} \mathrm{mg}^{-1}$.

Recombinant NAAAR was purified from E. coli
BL21(DE3), harboring pAr3 with a recovery rate of $8.7 \%$ by DEAE-Toyopearl and Sephacryl-S200 column chromatography. The specific activity of purified NAAAR was 1.08 $\mathrm{U} \mathrm{mg}^{-1}$, with a protein purification factor of 37.2. The purification results are summarized in Table 3. A SDSPAGE analysis of purified NAAAR showed a band of 41 $\mathrm{kDa}$, while the molecular mass determined by gel filtration was about $320 \mathrm{kDa}$ (Fig. 3). The protein appeared to consist of eight identical subunits.

\subsection{Effect of temperature and $p H$ on NAAAR}

The optimal temperature of this enzyme is $40^{\circ} \mathrm{C}$ when using $N$-acetyl-D-methionine as the substrate (Fig. 4A). After incubation of this enzyme at $45^{\circ} \mathrm{C}$ of $\mathrm{pH} 7.5$ for 30 min, this enzyme still had $80 \%$ of remaining activity. The maximum activity of NAAAR occurred between $\mathrm{pH} 6.8$ and 8.6 at $40^{\circ} \mathrm{C}$ (Fig. 4B).

\subsection{Effect of metal ions and chemical reagents on $N A A A R$}

NAAAR was incubated with various metal ions and reagents in $50 \mathrm{mM}$ Tris/ $\mathrm{HCl}$ buffer $(\mathrm{pH} 7.5)$, with relative activity was measured under assay conditions as described

Table 3

Purification of $N$-acylamino acid racemase from E. coli transformant

\begin{tabular}{lcllrr}
\hline Purification step & $\begin{array}{l}\text { Total protein } \\
(\mathrm{mg})\end{array}$ & $\begin{array}{l}\text { Total activity } \\
\text { (units) }\end{array}$ & $\begin{array}{l}\text { Specific activity } \\
\text { (units/mg) }\end{array}$ & $\begin{array}{c}\text { Purification } \\
\text { factor }\end{array}$ & $\begin{array}{c}\text { Yield (\%) } \\
\text { Crude cell extract }\end{array}$ \\
Toyopearl DEAE-650M & 3104 & 90.0 & 0.03 & 1 & 100.0 \\
Sephacryl S-200 HR & 187 & 41.7 & 0.22 & 7.7 & 46.3 \\
\hline
\end{tabular}



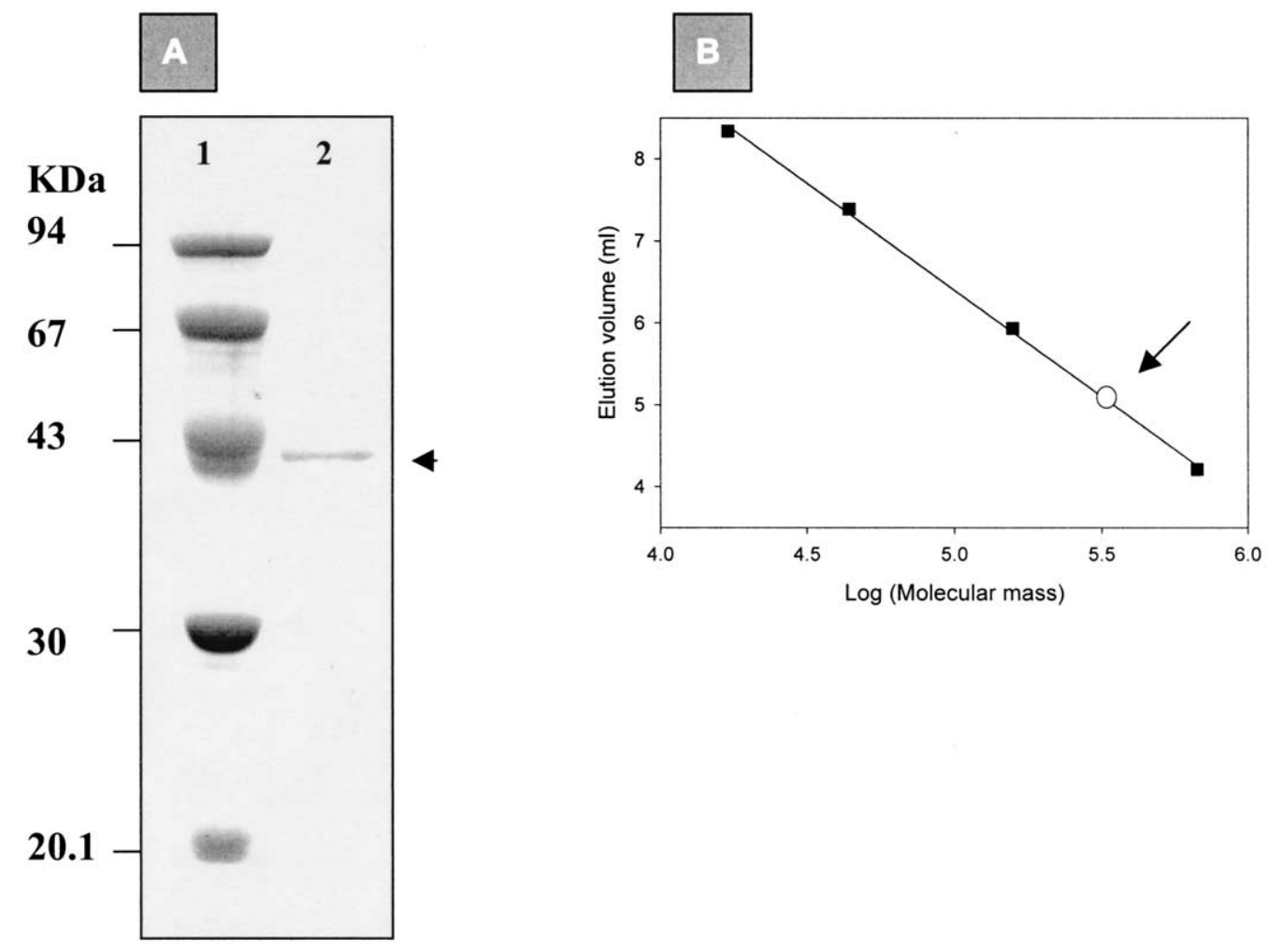

Fig. 3. SDS-PAGE analysis of the purified enzyme from E. coli BL21(DE3) cells harboring the recombinant plasmid pAr3 (A) and determination of the relative molecular mass of purified $N$-acylamino acid racemase by TSK G-3000 SW HPLC column (B). Lane 1, low molecular weight protein standard (Pharmacia); lane 2, purified $N$-acylamino acid racemase; arrow indicated the NAAAR protein.

in "Materials and Methods," except for the substitution of various metal salts with $\mathrm{CoCl}_{2}$. The effect of various ions upon NAAAR activity is shown in Table 4. The enzyme was significantly activated by $\mathrm{Co}^{2+}$ and $\mathrm{Mn}^{2+}$; a three- to four-fold stimulation of enzyme activity was also observed with $\mathrm{Mg}^{2+}$ and $\mathrm{Fe}^{2+}$. In contrast, $1 \mathrm{mM}$ of $\mathrm{Cu}^{2+}$ and $\mathrm{Ca}^{2+}$ completely inhibited the activity of NAAAR. However, the activity of NAAAR was also slightly inhibited by $10 \mathrm{mM}$ of $\mathrm{Ni}^{2+}$ and $\mathrm{Zn}^{2+}$ (Table 4). The reducing agents, $1 \mathrm{mM}$ DTT and $10 \mathrm{mM}$ 2-mercaptoethanol, completely inhibited the enzyme activity. These results indicate that DTT is more effective than 2-mercaptoethanol, in inhibiting NAAAR activity.

\subsection{Substrate specificity and enzyme kinetics}

Initial studies on the substrate specificity of homogeneous NAAAR were carried out with $25 \mathrm{mM}$ of substrate, and the enzyme was assayed using chiral-HPLC. The following $\mathrm{N}$-acetyl-D-methionine, $\mathrm{N}$-acetyl-L-methionine, $\mathrm{N}$ acetyl-D-tyrosine, $\mathrm{N}$-acetyl-L-valine, and $\mathrm{N}$-chloroacetylD-phenylalanine were good substrates (Table 5). The enzyme did not catalyze the racemization of D-methionine, L-methionine, or $\mathrm{N}$-acetyl-arginine. After incubation with NAAAR for 20 -h, the substrate conversion ratios were found to be around $50 \%$, including $N$-acetyl derivatives of methionine and leucine, and $\mathrm{N}$-acyl derivatives of aromatic amino acids such as $N$-acetyl-phenylalanine, $N$-acetyl-tyrosine, and $N$-chloroacetyl-phenylalanine (Table 5). Data reveal that $N$-acylamino acid racemase has a broad substrate range; however, $\mathrm{N}$-acetyl-D-methionine and $\mathrm{N}$-acetyl-Lmethionine are the best substrates.

This enzyme's activity obeys Michaelis-Menten kinetics. The $K_{\mathrm{m}}$ and $k_{\mathrm{cat}} / K_{\mathrm{m}}$ values were $27.8 \mathrm{mM}$ and $3.11 \times 10^{2}$ $M^{-1} \mathrm{~S}^{-1}$, respectively, for $N$-acetyl-D-methionine. It was also found that NAAAR was competitively inhibited by salicylhydroxamate, with a $K_{\mathrm{i}}$ value of $42.5 \mu \mathrm{M}$ (Fig. 5).

\section{Discussion}

$\mathrm{N}$-acylamino acid racemase is a useful enzyme for producing optically active amino acids. In this study, we have selected an $\mathrm{N}$-acylamino acid racemase producing strain, Amycolatopsis azurea CCRC13413, and cloned the aaar gene. We have demonstrated that the gene codes for $\mathrm{N}$ acylamino acid racemase, which can racemize $N$-acyl-derivative amino acids, but cannot act on amino acids. For $\mathrm{N}$-acyl derivatives of nonpolar or uncharged $\mathrm{R}$ groups of amino acids, the enzyme reaction preferred the L-form substrate; but when using $\mathrm{N}$-acyl derivatives of aromatic R groups of amino acids as the substrates, the enzyme reaction 


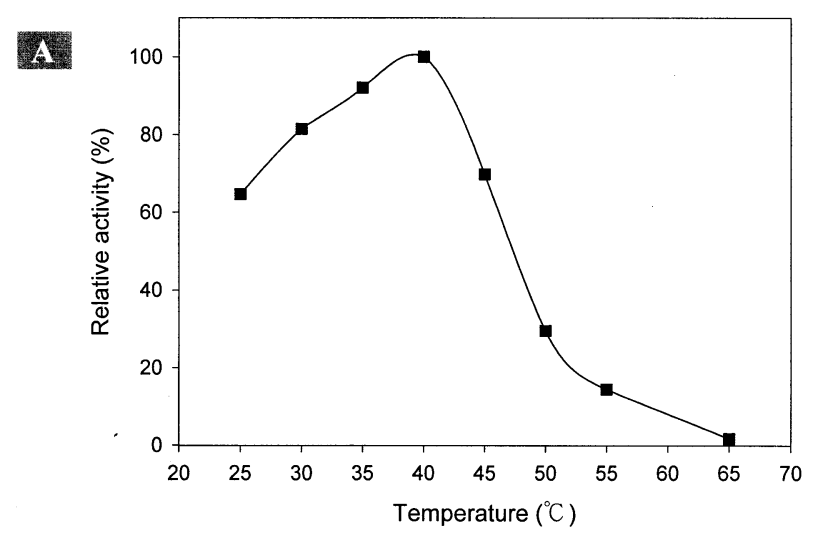

䊖

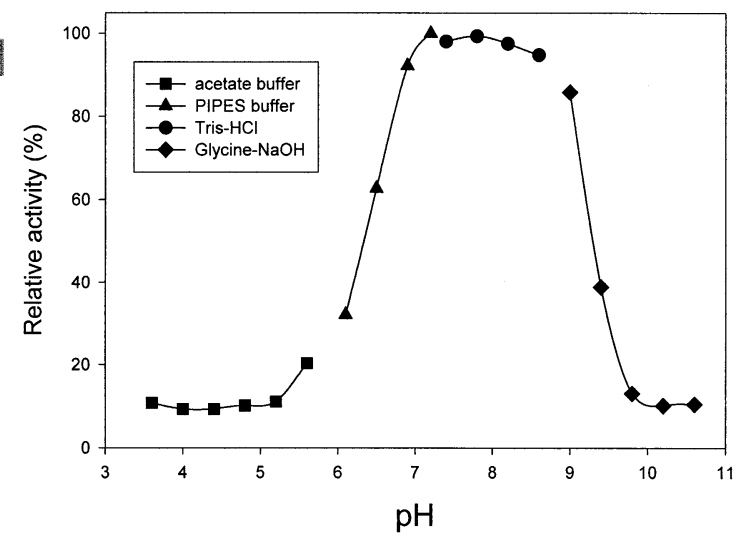

Fig. 4. Effect of temperature (A) and $\mathrm{pH}$ (B) on the activity of $\mathrm{N}$-acylamino acid racemase. The optimum temperature tests were done at different temperatures for $10 \mathrm{~min}$, and the optimum $\mathrm{pH}$ was determined by incubation of the enzyme between $\mathrm{pH} 3.6$ and 10.6. The enzyme activity was determined by the L-amino acid oxidase assay method, as described in "Materials and Methods."

preferred the D-form substrate (Table 5). This enzyme possessed broad substrate range. Comparing the substrate specificity of NAAAR among Amycolatopsis azurea CCRC13413, Amycolatopsis sp. TS-1-60 [7], and Amycolatopsis orientalis subsp. lurida [12], the NAAAR from Amycolatopsis azurea CCRC13413 can racemize the $N$ acetyl-D-tyrosine but Amycolatopsis sp. TS-1-60 cannot. The NAAAR from Amycolatopsis azurea CCRC13413 can racemize the $N$-acetyl-D, L-leucine but Amycolatopsis orientalis subsp. lurida cannot display this property.

From the sequence alignments between NAAAR of Amycolatopsis azurea CCRC 13413, Amycolatopsis sp. TS1-60, Amycolatopsis orientalis subsp. lurida and other putative NAAARs (Fig. 2), we derived the distributions of conserved regions between them. Thus far, the NAAAR is unsuitable for use in industrial applications. The enzyme activity and substrate inhibition must be improved. Before we obtaining the crystal structure of NAAAR, information
Table 4

Metal ions and reagents effect for the $N$-acylamino acid racemase

\begin{tabular}{lcc}
\hline Reagent & \multicolumn{2}{c}{ Relative activity $(\%)^{\mathrm{a}}$} \\
\cline { 2 - 3 } & $1 \mathrm{mM}$ & $10 \mathrm{mM}$ \\
\hline $\mathrm{None}$ & 100 & 100 \\
$\mathrm{LiCl}$ & 0 & $\mathrm{ND}$ \\
$\mathrm{NaCl}$ & 0 & $\mathrm{ND}$ \\
$\mathrm{KCl}$ & 0 & $\mathrm{ND}$ \\
$\mathrm{MgSO}_{4} \cdot 7 \mathrm{H}_{2} \mathrm{O}$ & 375 & 425 \\
$\mathrm{CoCl}_{2} \cdot 6 \mathrm{H}_{2} \mathrm{O}$ & 1270 & 907 \\
$\mathrm{NiCl}_{2} \cdot 6 \mathrm{H}_{2} \mathrm{O}$ & 228 & 83 \\
$\mathrm{ZnCl}_{2}$ & 98 & 48 \\
$\mathrm{CuCl}_{2}$ & 0 & 0 \\
$\mathrm{MnCl}_{2} \cdot 4 \mathrm{H}_{2} \mathrm{O}$ & 1090 & 1086 \\
$\mathrm{FeSO}_{4} \cdot 7 \mathrm{H}_{2} \mathrm{O}$ & 335 & 298 \\
$\mathrm{CaCl}_{2} \cdot 2 \mathrm{H}_{2} \mathrm{O}$ & 0 & $\mathrm{ND}$ \\
$\mathrm{FeCl}_{3} \cdot 6 \mathrm{H}_{2} \mathrm{O}$ & 110 & $\mathrm{ND}$ \\
$\mathrm{DTT}$ & 0 & 0 \\
$2-\mathrm{mercaptoethanol}$ & 70 & 0 \\
\hline
\end{tabular}

${ }^{\text {a }}$ Enzyme activity was assayed by HPLC method as described on Materials and Methods. ND, not detected.

about sequence alignments is valuable in performing protein engineering.

When we began studying this NAAAR, we were very interested in the enzymatic functions of microbial physiology. NAAAR from Amycolatopsis sp. TS-1-60 was originally classified as belonging to the muconate lactonizing

Table 5

Substrate specificity of $\mathrm{N}$-acylamino acid racemase

\begin{tabular}{rlcl}
\hline No. & Substrate & $\begin{array}{l}\text { Relative activity } \\
(\%)\end{array}$ & $\begin{array}{l}\text { Racemization } \\
\text { conversion ratio } \\
(\%)^{\mathrm{a}} \text { after } 20 \mathrm{hr}\end{array}$ \\
\hline 1 & $N$-acetyl-D-Met & 100.0 & 52.1 \\
2 & $N$-acetyl-L-Met & 102.3 & 49.6 \\
3 & $N$-acetyl-D-Tyr & 59.1 & 55.2 \\
4 & $N$-acetyl-L-Tyr & 25.5 & 57.3 \\
5 & $N$-acetyl-D-Val & 16.4 & 47.2 \\
6 & $N$-acetyl-L-Val & 39.8 & 43.0 \\
7 & $N$-acetyl-D-Leu & 8.6 & 47.4 \\
8 & $N$-acetyle-L-Leu & 28.1 & 46.2 \\
9 & $N$-acetyl-D-Phe & 27.3 & 56.4 \\
10 & $N$-acetyl-L-Phe & 15.6 & 50.4 \\
11 & $N$-Ch-D-Phe & 53.8 & 55.0 \\
12 & $N$-Ch-L-Phe & 21.3 & 48.0 \\
13 & $N$-acetyl-L-Ile & 7.5 & 38.3 \\
14 & $N$-acetyl-L-Thr & 3.5 & 12.2 \\
15 & $N$-acetyl-D-Ala & 0 & 20.6 \\
16 & $N$-acetyl-L-Ala & 0 & 11.4 \\
17 & $N$-acetyl-D-Asn & 0 & 14.2 \\
18 & $N$-acetyl-L-Arg & 0 & 0 \\
19 & D-Met & 0 & 0 \\
20 & L-Met & 0 & 0 \\
\hline
\end{tabular}

${ }^{a}$ Both of the relative activity and substrate racemization conversion ratios were assayed by the HPLC, method as described on "Materials and Methods." Relative activity was assayed at $30^{\circ} \mathrm{C}$, for $30 \mathrm{~min}$, in a standard reaction, with an exception of no further addition of L-aminoacylase in reaction mixture. 


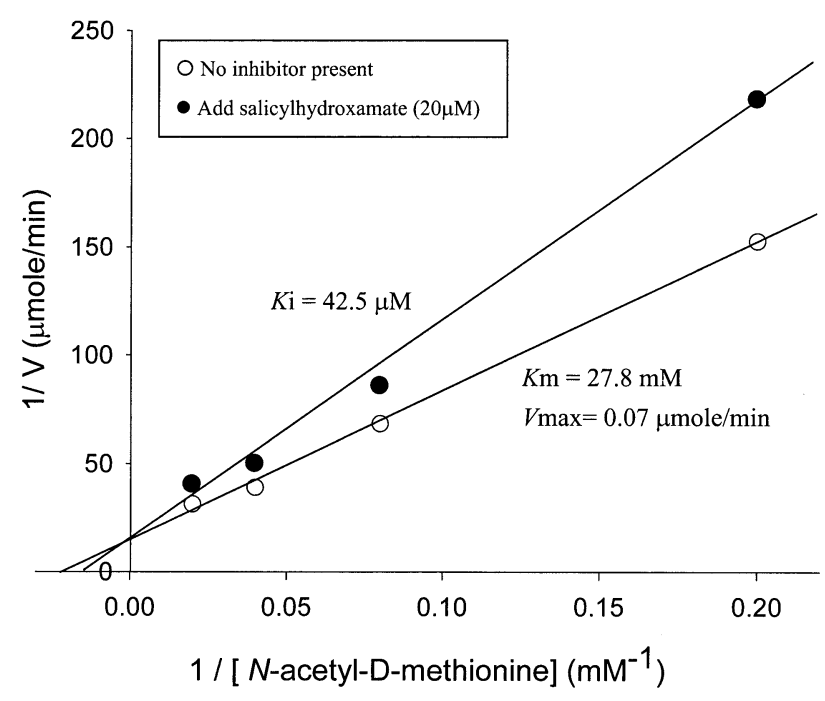

Fig. 5. Kinetic parameters of the $N$-acylamino acid racemase racemization reaction and reaction inhibition by salicylhydroxamate. The initial rate of racemase activity was measured at standard reaction conditions. The concentration of salicylhydroxamate was $20 \mu \mathrm{M}$, and that of $N$-acetyl-Dmethionine was 5 to $50 \mathrm{mM}$. The enzyme activity was determined by the L-amino acid oxidase assay method.

enzyme (MLE), a subfamily of the enolase superfamily [10]; furthermore, it has recently been considered to be an $o$-succinylbenzoate synthase (OSBS) [23]. Our results showed that NAAAR from Amycolatopsis azure CCRC 13413 produce racemization activity for $N$-acylamino acids. In our inhibition kinetics study, we also found that salicylhydroxamate, an analog of 2-hydroxy-6-succinyl-2, 4-cyclohexadiene carboxylate (SHCHC), competitively inhibited the activity of NAAAR with $K_{\mathrm{i}}$ of $42.5 \mu \mathrm{M}$ (Fig. 5). Furthermore, SHCHC was the reaction substrate of $o$-succinylbenzoate synthase. This revealed that NAAAR from Amycolatopsis azurea also has the OSBS property. Recently, Thompson et al. [24] elucidated the protein structure of OSBS from E. coli observing it as monomeric among crystal lattice, and reporting that it may possibly dimerize weakly in solution. However, our data (Fig. 3) and Tokuyama et al. [7], Verseck et al. [12] revealed that the active form of NAAAR from Amycolatopsis sp., should be octamers. Besides, the $o$-succinylbenzoate synthase gene of $E$. coli $(m e n C)$ and Bacillus subtilis (ytfD) have been demonstrated as located in a menaquinone biosynthesis gene cluster [23]. And it deserves to be mentioned that our unpublished data showed that the aaar gene of Amycolatopsis azurea doesn't fit within a menaquinone biosynthesis gene cluster. Even though the $N$-acylamino acid racemase has been considered to be $o$-succinylbenzoate synthase, we believe that the physiological functions of this enzyme still need further study. Among homologous proteins with $\mathrm{N}$-acylamino acid racemase, the YtfD of Bacillus subtilis has been proved to be an OSBS. The YtfD of Bacillus subtilis and OSBS of E. coli showed no activity for $N$-acylamino acid racemase [23]. According with previous reports and our study, we believed that the NAAAR of Amycolatopsis azurea, Amycolatopsis sp. TS-1-60, and Amycolatopsis orientalis subsp. lurida should provide alternative activities, partaking an important role in orthologous OSBSs' evolution.

Other putative NAAAR sequences from Aeropyrum pernix K1, Deinococcus radiodurans R1, and Thermoplasma acidophilum, have been found from searching data files for sequence similarity. None of these were proven to possess NAAAR activity as yet. Since enzymes have been found to possess an alternative activities [25], and the potential role of catalytic promiscuity is for successful use in protein engineering [26], in the future, we need further in depth studies between NAAARs of Amycolatopsis sp. and putative NAAARs.

\section{Acknowledgments}

This work was supported by a grant NSC 89-2311-B002-021-B31 and 88-2316-B-002-012-BI from the National Science Council of Taipei, Taiwan, Republic of China.

\section{References}

[1] Collins AN, Sheldrake GN, Crosby J. Membrane bioreactors for the production of enantiomerically pure $\alpha$-amino acids. In: Collins AN, Sheldrake GN, Crosby J, editors. Chirality in industry. New York: John Wiley and Sons, Inc., 1994. p. 372-97.

[2] Van Regenmortel MH, Muller S. D-peptides as immunogens, and diagnostic reagents. Curr Opin Biotechnol 1998;9:377-82.

[3] Kamphuis J, Meijer EM, Boesten WH, Sonke T, van den Tweel WJ, Schoemaker HE. New developments in the synthesis of natural and unnatural amino acids. Ann N Y Acad Sci 1992;672:510-27.

[4] Yang YB, Hsiao KM, Li H, Yano H, Tsugita A, Tsai YC. Characterization of D-aminoacylase from Alclaigenes denitrificans DA181. Biosci Biotech Biochem 1992;56:1392-5.

[5] Kim JG, Cheon YH, Kim HS. Directed evolution of a novel $\mathrm{N}$ carbamylase/D-hydantoinase fusion enzyme for functional expression with enhanced stability. Biotechnol Bioeng 2000;68:211-7.

[6] Tokuyama S, Hatano K, Takahashi T. Discovery of a novel enzyme, $\mathrm{N}$-acylamino acid racemase in an actinomycete: screening, isolation and identification. Biosci Biotech Biochem 1994;58:24-7.

[7] Tokuyama S, Hatano K. Purification and properties of thermostable $N$-acylamino acid racemase from Amycolatopsis sp. TS-1-60. Appl Microbiol Biotechnol 1995;42:853-9.

[8] Tokuyama S, Hatano K. Cloning, DNA sequencing, and heterologous expression of the gene for thermostable $N$-acylamino acid racemase from Amycolatopsis sp. TS-1-60 in Escherichia coli. Appl Microbiol Biotechnol 1995;42:884-9.

[9] Tokuyama S, Hatano K. Overexpression of the gene for $N$-acylamino acid racemase from Amycolatopsis sp. TS-1-60 in Escherichia coli and continuous production of optically active methionine by a bioreactor. Appl Microbiol Biotechnol 1996;44:774-7.

[10] Babbitt PC, Hasson MS, Wedekind JE, Palmer DR, Barrett WC, Reed GH, Rayment I, Ringe D, Kenyon GL, Gerlt JA. The enolase superfamily: a general strategy for enzyme-catalyzed abstraction of the $\alpha$-protons of carboxylic acids. Biochemistry-US 1996;35:16489-501.

[11] Tosa T, Mori T, Fuse N, Chibata I. Studies on continuous enzyme reaction. IV. Preparation of a DEAE-sephadex-aminoacylase column and continuous optical resolution of acyl-DL-amino acids. Biotechnol Bioeng 1967;9:603-15. 
[12] Verseck S, Bommarius A, Kula MR. Screening, overexpression, and characterization of an $\mathrm{N}$-acylamino acid racemase from Amycolatopsis orientalis subsp. lurida. Appl Microbiol Biotechnol 2001;55:354-61.

[13] Ausbel FM, Brent R, Kingstone RE, Moore DD, Seidman JG, Smith JA, Struhl K, editors. Current protocols in molecular biology. New York: John Wiley and Sons, Inc., 1993.

[14] Sanger F, Nicklen S, Coulson AR. DNA sequencing with chainterminating inhibitors. Proc Natl Acad Sci USA 1977;74:5463-7.

[15] Zhang Z, Schaffer AA, Miller W, Madden TC, Lipman DJ, Koonin EV, Altschul SF. Protein sequence similarity searches using patterns as seeds. Nucleic Acids Res 1998;26:3986-90.

[16] Thompson JD, Higgins DG, Gibson TJ. CLUSTAL W: improving the sensitivity of progressive multiple sequence alignment through sequence weighting, position-specific gap penalties, and weight matrix choice. Nucleic Acids Res 1994;22:4673-80.

[17] Péter A, Török G, Armstrong DW. High-performance liquid chromatographic separation of enantiomers of unusual amino acids on a teicoplanin chiral stationary phase. J Chromatogr A 1998;793:283-96.

[18] Bradford MM. A rapid, and sensitive method for the quantification of microgram quantities of protein utilizing the principle of protein dye binding. Anal Biochem 1976;72:248-54.

[19] Kawarabayasi Y, et al. Complete genome sequence of an aerobic hyper-thermophilic crenarchaeon, Aeropyrum pernix K1. DNA Res 1999;6:83-101.
[20] Kunst F, et al. The complete genome sequence of the gram -positive bacterium Bacillus subtilis. Nature 1997;390:249-56.

[21] Ruepp A, et al. The genome sequence of the thermoacidophilic scavenger Thermoplasma acidophilum. Nature 2000;407:508-13.

[22] White O, et al. Genome sequence of the radioresistant bacterium Deinococcus radiodurans R1. Science 1999;286:1571-7.

[23] Palmer DR, Garrett JB, Sharma V, Meganathan R, Babbitt PC, Gerlt JA. Unexpected divergence of enzyme function and sequence: " $N$ acylamino acid racemase" is $o$-succinylbenzoates synthase. Biochemistry-US 1999;38:4252-8.

[24] Thompson TB, Garrett JB, Taylor EA, Meganathan R, Gerlt JA, Rayment I. Evolution of enzymatic activity in the enolase superfamily: structure of $o$-succinylbenzoate synthase from Escherichia coli in complex with $\mathrm{Mg}^{2+}$ and $o$-succinylbenzoate. Biochemistry-US 2000; 39:10662-76.

[25] O'Brien PJ, Herschlag D. Catalytic promiscuity and the evolution of new enzymatic activities. Chem Biol 1999;6:91-105.

[26] Crameri AE, Raillard S-A, Bermudes E, Stemmer WPC. DNA shuffling of a family of genes from diverse species accelerates directed evolution. Nature 1998;391:288-91.

[27] Bullock WO, Fernandez JM, Stuart JM. XL1-Blue: a high efficiency plasmid transforming recA Escherichia coli strain with beta-galactosidase selection. BioTechniques 1987;5:376-9. 